\title{
Nauka i wiara
}

Mówi się często, że nauka wadzi się z wiarą. W rzeczywistości jednak to przedstawiciele tych dziedzin wiodą spór ze sobą. Dzieje się tak wtedy, gdy widzą tylko siebie i swój obręb badawczy, a wszystko inne lekceważą. Tymczasem nauka i wiara - to drogi dochodzenia do Prawdy. Ona jest zawsze na przodzie: przyzywa człowieka i często, jak linia horyzontu, ucieka przed nim. Chodzi oczywiście o prawdę bytu, będącego fundamentem sensu życia i drogowskazem do jego posiadania.

Nauki medyczne, dziś tak bardzo rozwinięte, nie są wszechmocne. A człowiek, o którego się troszczą, jakże często wymyka się ich ustaleniom. Choroba i zdrowie, chociaż poddane są prawom naturalnym, nie są nimi skrępowane i także człowiek potrafi wznieść się ponad to, co $\mathrm{w}$ nim należy do świata przyrody. Podobnie jest $\mathrm{z}$ teologią. W punkcie wyjścia mocuje się ona z potrzebą wyjaśnienia wiary. Wie jednocześnie, że wyjaśnienie to może przyjść z Biblii i księgi przyrody. Pismo Święte bowiem szanuje to, co Bóg mówi przez stworzony świat.

Ranga teologii na uniwersytecie jest inna od tej, jaką w nim posiadają nauki eksperymentalne. Tylko ona może stawiać pytania, które naukom przyrodniczym są potrzebne i wobec których są bezradne. Teologii na uniwersytecie nie wolno mierzyć statystyką lub ekonomią. Obraca się ona bowiem w obszarze jakości, a nie ilości.

Postulowana interdyscyplinarność badań szanuje metody właściwe poszczególnym dyscyplinom naukowym. Nie powinno się posługiwać nimi dla zysku lub kariery. Jedynym ich celem ma być poznanie Prawdy. Ona jedynie broni człowieka przed zniewoleniem. 